С. Н. Иванова. О решении проблем социального развития территорий: российская и зарубежная практика

Научная статья

УДК 332.145

DOI 10.18101/2304-4446-2021-1-43-48

\title{
О РЕШЕНИИ ПРОБЛЕМ СОЦИАЛЬНОГО РАЗВИТИЯ ТЕРРИТОРИЙ: РОССИЙСКАЯ И ЗАРУБЕЖНАЯ ПРАКТИКА
}

\author{
(C) Иванова Сембрика Нимаевна \\ доктор социологических наук, старший научный сотрудник, \\ Байкальский институт природопользования СО РАН \\ Россия, 670047, г. Улан-Удэ, ул. Сахьяновой, 8 \\ sambrika@mail.ru
}

\begin{abstract}
Аннотация. Статья посвящена российской и зарубежной практике регулирования социального развития территорий. Особое внимание в статье уделено проблемам развития инфраструктуры здравоохранения. Выделены основные тренды развития системы здравоохранения в России. Дан сравнительный анализ социального развития территорий регионального уровня России на основе методики оценки доступности услуг социальной инфраструктуры. Обоснован вывод о необходимости изменения подготовки медицинских кадров в сторону изменения длительности специализации, изменения подходов к оплате труда. Необходимо обратить внимание и на подготовку кадров для социальной сферы. Общественно значимым становится решение не только проблем развития инфраструктуры здравоохранения, но и социальной защиты населения, обеспечения жильем и сферы образования. В исследовании применялись методы сравнительного анализа и экономико-статистические методы.

Ключевые слова: социальное развитие; социальная инфраструктура; оценка доступности услуг; социальные стандарты; система здравоохранения; система образования; социальная политика.
\end{abstract}

\section{Для цитирования}

Иванова С. Н. О решении проблем социального развития территорий: российская и зарубежная практика // Вестник Бурятского государственного университета. Экономика и менеджмент. 2021. № 1. С. 43-48.

Проблемы социального развития территорий являются одним из главных объектов регулирования любого государства. Это, прежде всего, развитие социальной инфраструктуры как основа формирования человеческого капитала $[1 ; 2 ; 4]$. Социальная политика государства включает системы стандартизации, нормативы, контроля предоставления социальных услуг населению на национальном, региональном и муниципальном уровнях. Эффективность функционирования социальной инфраструктуры в полной мере отражается на сбалансированности территориального размещения населения, рабочих мест, соблюдении принципов социальной справедливости и равном доступе к социальным благам населения, проживающего на территориях. Имеющиеся проблемы территориальных диспропорций и межрегиональных противоречий в развитии социальной инфраструктуры должны непременно решаться, прежде всего, на национальном уровне [3].

Российская практика регулирования социального развития территорий реализуется на основе государственных минимальных социальных стандартов за счет 
бюджетов всех уровней и государственных внебюджетных фондов. В России действуют социальные стандарты прожиточного минимума (ПМ) - минимального уровня потребления материальных благ и услуг, включающего обязательные платежи и стоимость (минимальной) потребительской корзины (ПК) набора продуктов питания, непродовольственных товаров и услуг, необходимых для сохранения здоровья человека и обеспечения его жизнедеятельности. ПК пересчитывается не реже одного раза в пять лет. Прожиточный минимум рассчитывается в среднем на душу населения, а также отдельно для трудоспособного населения, пенсионеров и детей ежеквартально. Исходя из величины прожиточного минимума определяется число нуждающихся в социальном обеспечении, размер социальных пособий, а также объемы бюджетных потребностей на выплату социальных пособий.

На основе показателя минимума оплаты труда (МРОТ) регулируется оплата труда, а также рассчитываются социальные пособия, налоги, штрафы, нормативы. Социальные нормативы обеспеченности социальными услугами устанавливаются правительством и профильными министерствами социальной сферы. В некоторых регионах России действуют региональные социальные стандарты.

Всего в российской практике расчета социальных стандартов насчитывается более 550 показателей по социальной сфере.

В зарубежной практике также используются государственные минимальные социальные стандарты за счет бюджетов всех уровней, а также государственных внебюджетных фондов. Так, в сопредельном Казахстане также используется прожиточный минимум (ПМ) (для исчисления размеров базовых социальных выплат), минимальная заработная плата (МЗП), месячный расчетный показатель (МРП) (для исчисления штрафных санкций, расчета налогов и других платежей). В Китае минимальная зарплата рассчитывается по каждой провинции. Оплата представлена в двух видах, как минимальная заработная плата за полный рабочий день, так и почасовая минимальная заработная плата. В Монголии установлены минимальная заработная плата (МРОТ) и прожиточный минимум.

Особая значимость роли социальной инфраструктуры во всех странах мира возросла в 2020 г. в связи с пандемией коронавируса (COVID-19).

В России и во всех зарубежных странах были реализованы как экономикофинансовые, так и социальные меры, касающиеся сохранения бизнеса и поддержки занятости, социальной защиты и охраны здоровья населения. Новая политика осуществлялась во взаимодействии государственных и территориальных органов власти. Прежде всего, осуществлялась поддержка населения на основе социальных выплат, предоставления субсидий, грантов, льготного кредитования, отсрочки выплаты налогов, обязательных платежей, создания облегченных условий для оформления и получения выплат по безработице, социальному и медицинскому страхованию [7].

Переосмыслению значимости и необходимости пересмотра многих показателей развития территориального здравоохранения были подвергнуты многие регионы России. Современная модель здравоохранения, существующая в основном на базе советской системы здравоохранения, реализуется на основе обязательного медицинского страхования и некоторых элементах рыночных механизмов. Однозначным является вывод о необходимости повышения роли государствен- 
С. Н. Иванова. О решении проблем социального развития территорий: российская и зарубежная практика

ных методов управления общественным здоровьем населения наряду в условиях совершенствования конкурентной среды предоставления медицинских услуг негосударственными медицинскими организациями, разработки современных клинических медицинских технологий [6].

Как показывает анализ статистики, доля расходов государственного бюджета России на здравоохранение за период 1995-2019 гг. возросла от 2,1\% ВВП в 1995 г. до 3,5\% ВВП в 2019 г. Увеличились государственные расходы на здравоохранение на душу населения от 1.0 прожиточного минимума в 1995 г. до 2,4 прожиточного минимума в 2019 г. (табл. 1). Произошло снижение числа больничных организаций, от 9479 в 2005 г. до 5257 в 2018 г. Число негосударственных больничных организаций увеличилось от 293 в 2005 г. до 319 в 2018 г. Больничные организации частной формы собственности в 2018 г. составили 259, что почти в 2 раза больше, чем в 2010 г.

Число врачей, работающих в государственных медицинских организациях, снизилось от 602 тыс. чел. в 1990 г. до 552 тыс. чел. в 2019 г. Наблюдается рост занятости врачей в негосударственном секторе, от 68 тыс. чел. в 2016 г. до 87 тыс. чел. в 2019 г.

Занятость среднего медперсонала в государственном секторе медицины снижается от 1478 тыс. чел. в 1990 г. до 1259 тыс. чел. в 2019 г. В негосударственном секторе растет занятость среднего медперсонала от 148 тыс. чел. в 2015 г. до 177 тыс. чел. в 2019 г.

Таблица 1

Динамика показателей в сфере здравоохранения*

\begin{tabular}{|c|c|c|c|c|c|c|c|c|c|c|}
\hline & 1990 & 1995 & 2000 & 2005 & 2010 & 2015 & 2016 & 2017 & 2018 & 2019 \\
\hline $\begin{array}{l}\text { Государственные расходы } \\
\text { на здравоохранение (в } \\
\text { процентах к ВВП) }\end{array}$ & н/д & 2,1 & 2,1 & 3,2 & 3,4 & 3,4 & 3,6 & 3,1 & 3,2 & 3,5 \\
\hline $\begin{array}{l}\text { Государственные расходы } \\
\text { на здравоохранение на } \\
\text { душу населения / ПМ, раз }\end{array}$ & н/д & 1,0 & 0,9 & 1,6 & 2,0 & 2,0 & 2,2 & 1,9 & 2,2 & 2,4 \\
\hline $\begin{array}{l}\text { Занятых в области здра- } \\
\text { воохранения, врачей в } \\
\text { подчинении минздрава } \\
\text { (тыс. чел.) } \\
\end{array}$ & 602 & 566 & 609 & 608 & 626 & 544 & 544 & 548 & 549 & 552 \\
\hline $\begin{array}{l}\text { Занятых в области здра- } \\
\text { воохранения, врачей в } \\
\text { негосударственном сек- } \\
\text { торе (тыс. чел.) }\end{array}$ & н/д & н/д & н/д & н/д & н/д & н/д & 68 & 76 & 81 & 87 \\
\hline $\begin{array}{l}\text { Средний медперсонал в } \\
\text { подчинении минздрава, } \\
\text { (тыс. чел.) }\end{array}$ & 1478 & н/д & 1397 & 1351 & 1328 & 1310 & 1292 & 1266 & 1266 & 1259 \\
\hline $\begin{array}{l}\text { Средний медперсонал в } \\
\text { негосударственном сек- } \\
\text { торе (тыс. чел.) }\end{array}$ & н/д & н/д & н/д & н/д & н/д & 148 & 154 & 172 & 171 & 177 \\
\hline
\end{tabular}




\begin{tabular}{|l|c|c|c|c|c|c|c|c|c|c|}
\hline $\begin{array}{l}\text { Младший медпенсонал в } \\
\text { подчинении минздрава, } \\
\text { (тыс. чел.) }\end{array}$ & н/д & н/д & н/д & н/д & н/д & 599 & 547 & 424 & 287 & 265 \\
\hline Койки, тыс. ед. & 2038 & 1851 & 1672 & 1575 & 1340 & 1222 & 1197 & 1183 & 1152 & 1124 \\
\hline Заболевших, млн чел. & 96 & 100 & 106 & 106 & 111 & 114 & 115 & 115 & & \\
\hline Заболевших, на 1 врача & 160 & 177 & 175 & 174 & 178 & 210 & 212 & 209 & 209 & 208 \\
\hline Заболевших, на 1 койку & 47 & 54 & 64 & 67 & 83 & 93 & 96 & 97 & 100 & 102 \\
\hline Летальность, \% & & & 1,3 & 1,4 & 1,5 & 1,7 & 1,8 & 1,8 & 1,9 & 2,0 \\
\hline
\end{tabular}

* составлено и рассчитано автором по ${ }^{1}$

Наиболее актуальным в процессе оценки развития социальной инфраструктуры, на наш взгляд, является такой критерий, как оценка доступности услуг социальной сферы. Методика предполагает сравнительный анализ суммарных индексов доступности услуг социальной инфраструктуры предыдущего и текущего года [5]. При расчете суммарного индекса доступности услуг использованы показатели социального развития эталонной территории с максимальными значениями. Регионы России были дифференцированы по уровню доступности услуг социальной сферы на 3 уровня: низкий (до 0,35), средний $(0,36-0,66)$, высокий $(0,67-1,00)$ [9]. Согласно расчетам, для большинства регионов России характерен средний уровень доступности услуг социальной сферы. Высокий уровень доступности социальных услуг наблюдается только на 8 территориях (Республика Алтай, Саха (Якутия), Тыва, Магаданская область, Забайкальский край, Еврейская автономная область, Ненецкий автономный и Чукотский автономные округа).

В России разрешение проблем социального развития территорий должно стать одной из главных задач системы государственного управления как социального государства. Прежде всего, необходимо изменение подходов и методов формирования социальной политики на основе пересмотра действующей практики финансирования социальных расходов, повышения доступа к социальным услугам на основе совершенствования стандартов и нормативов, развития государственно-частного партнерства в социальной сфере.

Особое внимание должно уделяться подготовке кадров для социальной сферы. В контексте зарубежной практики организации медицинской помощи, подготовки и использования медицинских кадров заслуживает внимания практика разделения труда между врачами и средним медицинским персоналом, в результате снижающая объем функций, выполняемых врачами [8]. В российской системе здравоохранения необходима оптимизация подготовки медицинских кадров в сторону изменения длительности специализации, совершенствования подходов к оплате труда. Общественно значимым становится решение не только проблем развития инфраструктуры здравоохранения, но и социальной защиты населения, обеспечения жильем и сферы образования.

1 Здравоохранение в России. 2019. Стат. сб. Росстат. М., 2019. 170 с.; ЕМИСС государственная статистика. URL: www.fedstat.ru/indicator (дата обращения: 25.12.2020) (Текст : электронный); Регионы России. Социально-экономические показатели. 2019: Стат. сб. / Росстат. М., 2019. 1204 с. 
С. Н. Иванова. О решении проблем социального развития территорий: российская и зарубежная практика

Благодарность

Работа выполнена в рамках государственного задания БИП СО РАН. Проект ААААА21-121011590039-6 (мнемо-код 0273-2021-0003)

\section{Литература}

1. Башкуева Е. Ю. Региональные проблемы системы здравоохранения в условиях модернизации (по материалам Республики Бурятия) // Ойкумена. 2015. № 1(32). С.100-112.

2. Башкуева Е. Ю. Ресурсное обеспечение системы здравоохранения Сибирского федерального округа: состояние и перспективы // Вестник Бурятского государственного университета. Экономика и менеджмент. 2017. № 4. С. 23-32.

3. Дагбаева С. Д.-Н. Проблемы и противоречия развития социальной сферы в российской и зарубежной практике // Общество: социология, психология, педагогика. 2018. № 12. С. 40-43. doi.org/10.24158/spp.2018.12.5.

4. Дагбаева С. Д.-Н. Территориальные проблемы развития социальной инфраструктуры // Фундаментальные исследования. 2019. № 4. С. 38-42. doi.org/10.17513/fr.42435.

5. Иванова С. Н. Ранжирование территорий регионального и локального уровней по доступности услуг социальной сферы // Экономика и управление: научно-практический журнал. 2020. №4 (154). С.131-136.

6. Сквирская Г. П., Волнухин А. В. Основные направления совершенствования деятельности в области общественного злорровья и управления здравоохранением в современных условиях Российской Федерации // Современные проблемы здравоохранения и медицинской статистики. 2020. № 2. С. 348-366.

7. Социальный бюллетень. Социальная политика в зарубежных странах в условиях пандемии / В. Трубин [и др.] / Аналитический центр при Правительстве Российской Федерации. 2020. 37 с.

8. Шейман И. М., Шевский В. И. Кадровая политика в здравоохранении: сравнительный анализ российской и международной практики // Вопросы государственного и муниципального управления. 2015. № 1. С. 143-167.

9. Ivanova S. N. Typology of territories by the accessibility of social services (on the example of the Great Silk Road zone of influence) // Journal of Environmental Management and Tourism. 2020. T. 11. № 3 (43). C. 571-578. DOI: 10.14505/jemt.v11.3(43).09.

Статья поступила в редакцию 21.01.2021; одобрена после рецензирования 28.01.2021; принята к публикаичи 29.01.2021.

\section{ON SOLUTION TO THE PROBLEMS OF TERRITORIES’ SOCIAL DEVELOPMENT: RUSSIAN AND FOREIGN PRACTICE}

Sembrika N. Ivanova

Dr. Sci. (Sociol.),

Senior Researcher,

Baikal Institute of Nature Management SB RAS

8 Sakhyanovoy St., Ulan-Ude 670047, Russia

sambrika@mail.ru

Abstract. The article considers Russian and foreign practice of regulating the social development of territories. Particular attention is paid to the problems of public health infrastructure. We have emphasized the main development trends in Russian healthcare system. Based on the methodology for assessing the availability of social infrastructure services, we present a comparative analysis of the social development of Russian regions. We have con- 
cluded that the duration of specialization of medical personnel, and approaches to remuneration should be changed. It is necessary to pay attention to training personnel for the social sector. It is becoming socially important to solve not only the problems of developing the healthcare infrastructure, but also providing welfare of the population, housing and education. The study used methods of comparative analysis, economic and statistical methods.

Keywords: social development; social infrastructure; assessment of service availability; social standards; healthcare system; education service; social policy. 